\title{
What will the Future Bring? Work, Digitalization and Social Protection under Society 5.0
}

\author{
Gelecek Ne Getirecek? Toplum 5.0 Kapsamında Çalışma, Dijitalleşme ve \\ Sosyal Koruma \\ DANIJELA BAGARIĆ* \\ VALENTINA FRANCA** \\ * Ph.D. Candidate, University of Ljubljana, Faculty of Administration, Gosarjeva ul. 5, 1000 Ljubljana, \\ Slovenia, E-mail: danijela.bagaric@fuds.si \\ (D) https://orcid.org/0000-0003-2737-0442 \\ ** Dr. Senior Lecturer, University of Ljubljana, Faculty of Administration, Gosarjeva ul. 5, 1000 Ljubljana, \\ Slovenia, E-Mail: valentina.franca@fu.uni-lj.si \\ (D) https://orcid.org/0000-0001-6532-7336
}

\begin{abstract}
Digitalization, the process of converting information into a digital format, further develops people's behaviour, skills and knowledge, especially that of digital natives, to use digital applications and technology. Society 5.0 may be too vague to function strategically, but it does place us at the centre of the ongoing technological revolution, and better facilitates proactivity. Globally, men generally participate in labour markets more than women, but this gender gap in participation rates has been sharply declining in recent decades. Turkey's significant structural and social change of late is expected to make it easier for women to enter the labour market, but their participation in the labour market is still low.
\end{abstract}

Keywords: Digitalization, Society 5.0, Labour market, Women, Turkey

Öz: Bilgiyi dijital bir formata dönüştürme süreci olan dijitalleşme, insanların, özellikle dijital yerlilerin davranışların, becerilerini ve bilgilerini dijital uygulamaları ve teknolojiyi kullanmak için daha da geliştirir. Toplum 5.0, stratejik olarak işlemek için çok belirsiz olabilir, ancak bizi devam eden teknolojik devrimin merkezine yerleştirmekte ve proaktifliği daha başarll biçimde gerçekleştirmektedir. Küresel olarak, erkekler genellikle işgücü piyasalarına kadınlardan daha fazla katılır, ancak katılım oranlarındaki bu cinsiyet farkı son yıllarda keskin bir şekilde azalmaktadır. Türkiye'nin son dönemdeki önemli yapısal ve sosyal değişiminin kadınların ișgücü piyasasına girișini kolaylaștırması beklenmekle birlikte, işgücü piyasasına katılımları hala son derece düşük düzeydedir.

Anahtar kelimeler: Dijitalleşme, Toplum 5.0, İşgücü piyasası, Kadınlar, Türkiye

\section{Introduction}

Human capital is a key driver of sustainable economic and social development, so long-term investment in it is necessary. However, women, half of all human capital, are underutilized and undervalued, and sustainable economic growth, be it national or global, requires their better integration into labour markets to optimally utilize their skills and knowledge, which will reduce poverty, gender and income 
inequality, increase economic growth and per capita income, and facilitate better governance, business performance, innovation, social welfare, and sustainable development. ${ }^{1}$

The pandemic has revealed cracks in all sectors of society and internet connection is becoming increasingly essential, so Society 5.0 strives to better incorporate technology into our daily lives to mitigate the adverse effect of these fault lines, and this incorporation is particularly accelerated in terms of digital natives. This change needs to be understood at the workplace, in education and generationally, as digital and computer skill are increasingly needed by employers. China leads the world with the largest number of STEM graduates. The largest companies use artificial intelligence, and Chinese companies are foremost, followed by those in the US and Europe. Organizations must strongly commit to the technological training of their staff: the European Union attests that $45 \%$ of all employment will be digital in nature in 2021 and the European Center for the Development of Vocational Education and Training projects that $90 \%$ of all employment will require digital skills by 2025, with the cross-cutting skills most required being creativity (47.2\%) and solving complex problems (43.8\%); furthermore, $50 \%$ of current employment activity globally could be automated by $2055 .^{2}$

Accordingly, labour markets require talent that is diverse in terms of gender and age, and awareness of this must be raised. The role of women in science is highlighted, but social stereotyping means that many still believe women do not have the requisite skills to pursue these professions; there are also few female role models because most women soon lose interest in such professions and stigmatization leads to them underestimating their abilities at an early age. Gender and technological bias must be eliminated, and Society 5.0 better facilitates our understanding of the symbiosis of humans and technology to do so. ${ }^{3}$

Gender equality is integral to Turkey's legislative and institutional frameworks, but weak legal enforcement and low quality support services mean there are still gender gaps in terms of employment, decision-making, education and health. Turkey's government has taken positive steps to improve gender equality, as outlined in its action plans for education and employment, yet these plans have yet to be fully implemented, or systematically monitored: the legislative and institutional mechanisms necessary for achieving work-family balance as a fundamental component of national policy to promote women's employment are still lacking. Turkish gender equality legislation has changed for the better, but it faces many obstacles. Women's rights are key to Turkey's accession to the European Union and its government has legislated to eliminate discrimination against women and ensure equal opportunities. Gender equality is a fundamental right enshrined in the Charter of Fundamental Rights of the European Union, and women's economic empowerment must include their equal participation in decision-making.

\footnotetext{
${ }^{1}$ Karaalp-Orhan, Hacer Simay. "What are the Trends in Women's Labour Force Participation in Turkey?", European Journal of Sustainable Development, 6/3 (2017), p.304.

2 "Sociedad 5.0: La Profesión Del Futuro", Management Magazine, May 14, 2021, https://www.magazine management.gm-bolivia.com/sociedad-5-0-la-profesion-del-futuro/.

${ }^{3}$ Carlo Alviggi, Sandro C. Esteves, Raoul Orvieto et al., "COVID-19 and Assisted Reproductive Technology Services: Repercussions for Patients and Proposal for Individualized Clinical Management", Reproductive Biology and Endocrinology, 18 (2020), https://rbej.biomedcentral.com/articles/10.1186/s12958-020-00605-z.
} 


\section{Methodology}

We adopted a mixed-method approach, combining systematic review techniques and more traditional strategies, to review the literature. We explored how new forms of work and digitalization affect social welfare generally and in Turkey specifically, and the impact of digitalization on the future of work, especially in relation to the lowest paid, with an emphasis on gender equality, that is, the widespread, rapid change triggered by advanced technology and rapid digitalization on welfare, current forms of work, social relations, and society's general organizational forms?

Our analysis is based on several scientific teaching methods and includes secondary sources, such as foreign literature, scientific and professional articles, statistics, and international and Turkish legal sources. Our theoretical starting points were defined by our methodology: we summarized the findings of other authors using the compilation method and compared facts, phenomena, processes and techniques for individual content sets using the comparison method.

\section{Labour Market Trends Globally and in Turkey}

The European Union has developed a complex, hybrid governance system, combining traditional hard law, soft policy instruments, and a wide range of actors and financial mechanisms to promote gender equality. ${ }^{4}$ By the mid-1990s, EU directives had been adopted on equality in relation to pay, working conditions, parttime work, self-employment, social security, pensions, the burden of proof in cases of discrimination, the protection of pregnant workers, access to goods and services, and parental leave. Soft policy instruments have been used since the 1970s, including Council and Commission recommendations, resolutions and action programs, to extend EU competence when coordinated action is desired, and these address issues such as the provision of childcare, the balanced participation of men and women in the EU and decision-making processes, broadening the EU's focus on the labour market. Soft instruments have therefore been the priority in terms of gender equality, where it has been difficult for Member States to reach consensus. ${ }^{5}$

Patterns in the structure of employment, working conditions and social security systems are adapting and concomitantly shaping the forces driving change. Demographic change, ICT innovation and diffusion, and the global expansion of the market economy in combination have engendered major change in the workplace and labour market. ${ }^{6}$ The disappearance of trade barriers, investment, cheaper transport and rapid technological progress since the mid-1980s have made it increasingly feasible to separate production processes and locate them in different countries to take advantage of lower costs, raw material availability and favourable policies. Global production systems have evolved and established linkage between the product and labour markets of the developed and developing countries, and these systems can be classified according to whether they are customer, manufacturer, or, increasingly since the mid-1990s, Internet-oriented. Decent work encom-

\footnotetext{
${ }^{4}$ Ayşe İdil Aybars, Paul Copeland and Dimitris Tsarouhas, "Europeanization without Substance? EU-Turkey Relations and Gender Equality in Employment", Comparative European Politic, 17/5 (2019), p.783.

${ }^{5}$ Aybars, Copeland and Tsarouhas, "Europeanization Without Substance?", p.786.

${ }^{6}$ International Labour Organization, "Cambios en el Mundo de Trabajo", Conferencia Internacional Del Trabajo 95.a Reunión, 2006, p.22, https://www.ilo.org/public/spanish/standards/relm/ilc/ilc95/pdf/rep-i-c.pdf.
} 
passes opportunity, income, rights, participation, recognition, family stability, personal development, gender justice and equality.

In Turkey, most young women, the majority of whom are poorly educated, enter the labour market but soon leave due marriage, low wages, household responsibilities and a lack of childcare support; additionally, Turkish women generally leave the labour market by the age of 45. As of April 2017, more women than men are unemployed and their employment rate is significantly lower than that for men. According to Turkstat data from 2017, 29\% of women and $65.7 \%$ of men in the age group 15 to 64 are employed, and young women in Turkey face the highest risk of unemployment. Population age composition is an important demographic factor influencing labour market participation rates: the increase in the share of the population aged 15 to 64 has led to an increase in labour market participation. In general, labour market participation rates for men are higher than that for women for all age groups. EU labour market participation rates for women are higher than that for OECD countries for all age groups. Compared to the EU and OECD, labour market participation in Turkey is very low for all age groups. EU and OECD labour market participation rates for women are highest in the 40 to 44 age group, while labour market participation rates for women in Turkey are highest in the 25 to 29 age group. ${ }^{7}$

According to statistics on labour market inclusion published by Turkstat in 2017, the main reasons why women leave paid employment are domestic work (55.3\%), disability, illness and age (13.4\%) and education (11.6\%). Data are valid for $2016 .{ }^{8}$

The inclusion of women in Turkey's labour market has decreased significantly in recent years, doing so especially in $2004(24.8 \%)$ because of the structural transformation caused by the contraction of its agricultural sector, migration, and urbanization. Rural women work unpaid in family businesses and provide childcare while doing farm work. In the case of household relocation from rural to urban areas, women cannot participate in the labour market because they are full-time housewives who only occasionally participate in the informal economy, and this significantly affects employment rates.

Many women had moved from the informal agricultural economy to the formal economy by 2012, though rates for the former were still very high, and legislation to increase the employment of women and their protection at work, and better social security incentives for those employing women over the age of 18 played a major role in this move. Despite progress, labour market integration has failed to promote gender equality and female empowerment. Legal status change significantly impacts on the participation of women in the labour market and single women make up a larger share of the labour market than married women. Turkey's main labour market challenges are its low level of female participation in the labour market, high level of informal employment, inadequate mechanisms for directing social benefit recipients to employment and weak education-employment relationship, and these are major obstacles to economic growth. Turkish women with children face many socio-cultural barriers in terms of formal employment and this determines their limited, post-marriage labour market participation: most women

\footnotetext{
7 Turkish Statistical Institute, "Labour Force Statistics", 2021, http://www.turkstat.gov.tr/PreHaberBultenleri.do?id=33778. 8 "Labour Force Statistics".
} 
leave the formal labour market when they marry, or have children. Gender inequality is strong in Turkey in both the private and public spheres. Turkey's formal employment rate for women is only half the EU average and a large proportion of its women leave school early. Many young Turkish women are actively involved domestically and in the informal economy, representing $30 \%$ of female employment in Turkey. ${ }^{9}$

Women are virtually absent from politics and public life, and urbanization and modernization will take some time to compensate for this imbalance due to the recent revival of traditional gender norms. The family remains the foundation of Turkish society, providing social and financial support, and employment, but rapid change and growing prosperity have affected the quality of society and social cohesion. Confidence has improved in urban areas and decreased in rural areas, suggesting that urbanization negatively affects traditional social relationships. Confidence in the government, however, decreased in Turkey between 2012 and 2017. Increasing economic prosperity seems to have weakened social cohesion, at least in the short run. One of the most important challenges facing Turkey is its low level of women participating in the labour market and politics. While legislation and action plans are being implemented, this is not enough. ${ }^{10}$

Graph 1. Employment in Terms of Marital Status in Turkey

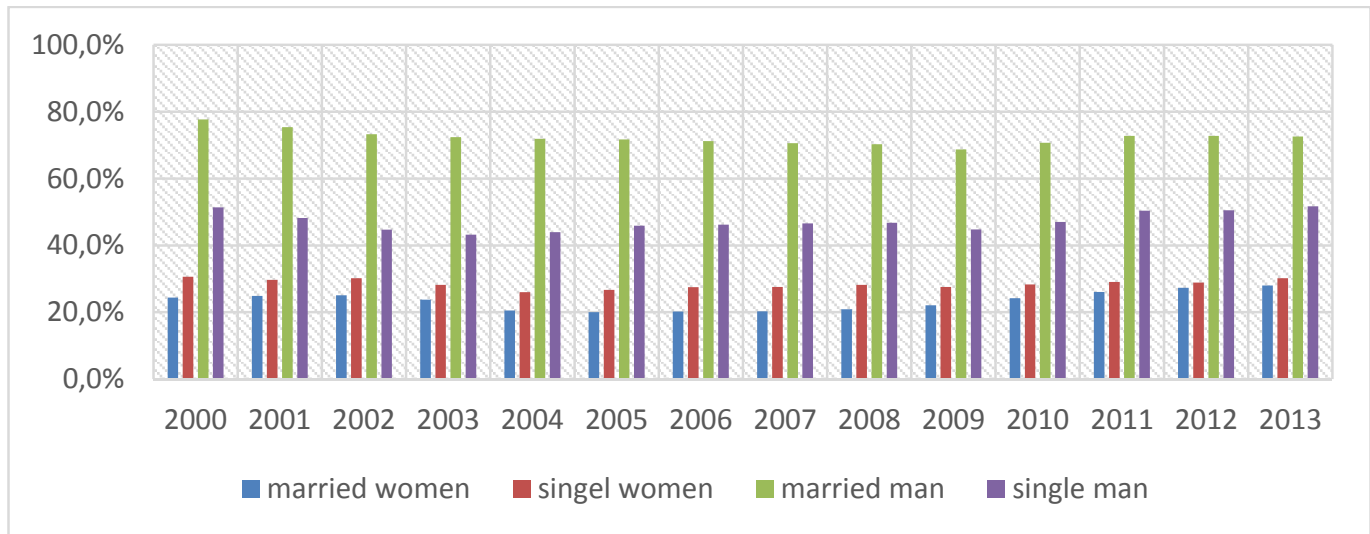

Source: Compiled from Turkstat by authors.

Graph 1, which presents the employment rates of married and single men and women, evidences the obvious differences between married women and men on the one hand, and single women and men on the other. Single men represented $47.2 \%$ of total employment on average between 2000 and 2013, while single women consistently represented approximately $28.5 \%$ year on year for the same period. The employment rate for women has improved since 2004 but not significantly.

\section{Global Epidemics and Catastrophes Affect Health, Poverty and Social Welfare Solidarity}

The COVID-19 epidemic directly affects stress and anxiety: the resulting lifestyle change, including social isolation and loneliness, distance learning and homework,

\footnotetext{
${ }^{9}$ Eurofound, Trends in Quality of Life - Turkey: 2003-2012 (European Quality of Life Survey (EQLS), Luxembourg: Publications Office of the European Union, 2014, p.2. https://www.eurofound.europa.eu/sites/ default/files/ef_publication/field_ef_document/ef1440en.pdf.

${ }^{10}$ Trends in Quality of Life Turkey: 2003-2012, p.2.
} 
reduced healthy lifestyle opportunity, employment and income insecurity, and additional burden on health care systems negatively affect physical and psychological health, particularly that of those already experiencing mental health problems. Staying at home and social isolation during health pandemics have a lasting effect on the mental health of children and adolescents, particularly in relation to fear of infection and prolonged isolation, boredom and frustration, lack of personal space, loss of contact with peers and other adults, and reduction in material well-being. For children in some families, pre-existing stressors may increase, including poverty, poor housing conditions, social isolation and limited access to quality health care. In the elderly, however, considerable distress, which is even greater for those living alone or in long-term care, is caused by fear of infection, change in daily routine, restriction on their independence, and loneliness. ${ }^{11}$ Equality between men and women is one of the sustainable development goals threatened by the pandemic. Everything indicates that the health, social and economic crisis generated by COVID-19 will increase the gender gap. Although coronavirus infection does not understand age, older people are at greater risk of infection leading to serious illness. In fact, the death rate from COVID-19 for those over 80 is five times higher than in the rest of the population. Overall, the COVID-19 pandemic has mostly affected women. Let's look at some examples. It is estimated that $67 \%$ of medical staff are female. Certainly, countries with poorer health care systems face even greater problems during a pandemic, especially when it comes to access to maternal health services.

On March 20, 2021, Turkey withdrew from the Istanbul Convention, which primarily aims to protect women from violence. The Council of Europe Convention on Preventing and Combating Violence against Women and Domestic Violence was signed by the current president of Turkey in Istanbul in 2011, where it was adopted. The document, which requires countries to introduce a legal framework to protect women from violence, has been signed by 45 countries and the European Union. The decision to withdraw from the Istanbul Convention further jeopardizes gender equality, especially at a time when violence against women around the world is on the rise. During the COVID-19 pandemic, however, the violence only increased. The Istanbul Convention is the latest and more detailed instrument on women's rights, which, together with the United Nations Declaration on the Elimination of Violence against Women, the Convention on the Elimination of All Forms of Discrimination against Women and the Beijing Platform for Action, is a plan to eliminate violence against women and girls. ${ }^{12}$

The work scenario after the health pandemic implies a series of changes such as the recovery of economic activity, uncertainties in the face of an uncertain future, the need to ensure effective protection against the coronavirus, the reorganization of workspaces and guidelines, that undoubtedly have an effect on the psychological well-being of workers and their job performance. COVID-19 pandemic further

\footnotetext{
${ }^{11}$ Urška Sodja, "Vplivi Covid-19 Na Nekatere Vidike Kakovosti Življenja in Družbene Blaginje", Kratke Analize, UMAR. 2020. https://www.umar.gov.si/publikacije/kratke-analize/publikacija/news/vplivi-covid-19na-nekatere-vidike-kakovosti-zivljenja-in-druzbene-blaginje/?tx_news_pi1\%5Bcontroller\%5D=News\&tx_ news_pi1\%5Baction\%5D=detail\&cHash=f042328151b2e46bd626b94ac212a215.

12 "Turkey: Withdrawal From Istanbul Convention is a Pushback against Women's Rights, Say Human Rights Experts", United Nations Human Rights Office of the High Commissioner (OHCHR), March 23, 2021, https://www.ohchr.org/en/NewsEvents/Pages/DisplayNews.aspx?NewsID=26936\&LangID=E.
} 
complicated that situation. ${ }^{13}$ Progress in terms of gender equality in the workplace has been reversed, and obstacles to accessing reproductive health have multiplied. The crisis has certainly hit women first, most of whom work in the unregistered sector in Turkey. These are the first to lose jobs and income. Precisely because they are employed in the informal sector, during the crisis COVID-19 they were deprived of all the benefits that made it possible to protect employees during a pandemic.

\section{The Repercussions and Effects of New Work Forms}

Digitalization affects companies of all sizes. On the one hand, companies need to digitize internal processes; on the other, they need to develop new services and digital business models by identifying new customer need in relation to their acceptance of digital services and applications; companies must digitally innovate to be successful in the digital age, a typical paradigm being establishing cultures of innovation to best develop digital processes, services and business models. Companies must also develop digital innovation strategies to manage digitalization and train employees to meet the challenges of the digital age and proactively participate in digital change. Digitalization has forced companies to align their marketing and sales activities with digital development. Digitalization's impact on the working poor needs to be addressed.

We cannot exactly predict what the future of work will bring, but change is taking place and it requires management. We do know, however, that digitalization is transforming existing jobs and requires new skills to perform new tasks, meaning the current workforce must be redirected or replaced. Digitalization creates new jobs and makes others redundant; it radically reshapes the nature of work and redefines the boundaries of production, distribution, and consumption.

Digitalization is one of the most dynamic phenomena of our age, and in it opportunity and risk are closely intertwined. Future development is likely to be complex, with start-ups and small businesses appearing alongside the traditional, and flexibility is essential, but we are not fully aware of how it will affect employment. As a result, there is growing concern about declining employment rates and EU labour market inefficiency; constructive government and social partner cooperation and increased awareness are crucial. Pursuant to the diverse socio-economic structures and different levels of economic development in the EU, it may be necessary to carry out specific analyses and use specific approaches to manage the impact of digitalization on labour markets and employment. Collective bargaining must be supported at all levels, especially in industries and companies affected by digitisation, to prevent an increase in income inequality. Digitalized work produces large amounts of personal data on where, what, when and with whom employees work, and its seamless flow of information creates opportunities for efficiency; however, it also enables intrusive employee control, which threatens established standards of privacy at work. ${ }^{14}$

\footnotetext{
13 "Cómo Asegurar el Bienestar en la Vuelta al Trabajo Tras la Pandemia por COVID-19", Infocop Online, June 3, 2021, http://www.infocop.es/view_article.asp?id=16886.

14 "Opinion of the European Economic and Social Committee on the Impact of Digitalisation on the Service Sector and Employment in the Context of Industrial Change", European Economic and Social Committee, Brussel, 2016, https://webapi2016.eesc.europa.eu/v1/documents/eesc-2015-00765-00-03-ac-tra-sl.docx/content.
} 


\section{Social Protection and Society 5.0.}

The brutal challenge to our systems and models of social and industrial organization that the Coronavirus crisis poses will open windows of opportunity for Industry and Society 5.0. This is not a fiction, but a model already anticipated by the Japanese government, which is why Japan was prepared for this crisis and has managed it so well. The Society and Industry 5.0 model is based on the massive accumulation of data in real time from all sectors, excellence culture and lean manufacturing.

Japan has developed a strong Society 5.0 concept to take full advantage of the ongoing technological transformation to benefit all of its citizens and solve the concomitant problems. In recent years, Japan has been developing a concept to solve its own problems of aging, infertility and competitiveness, and harness technological innovation to build a better country and world, that is, a Society 5.0 in which no one is left behind. Japan's Society 5.0 places the individual at the centre of the technological transformation that took place during the 4th Industrial Revolution, which socially goes further than Germany's Industry 4.0 and China 2025. The Japanese government and the Keidanren Association supported initiatives, such as the next artificial intelligence strategy and the Connected Industry initiative, to better enable this and the Ministry of the Economy, Trade and Industry promoted them, and in doing so, Japan hopes to contribute to the world and promote compliance with sustainable development goals for $2030 .{ }^{15}$

\section{Infograph 1. From Society 1.0 to 5.0}

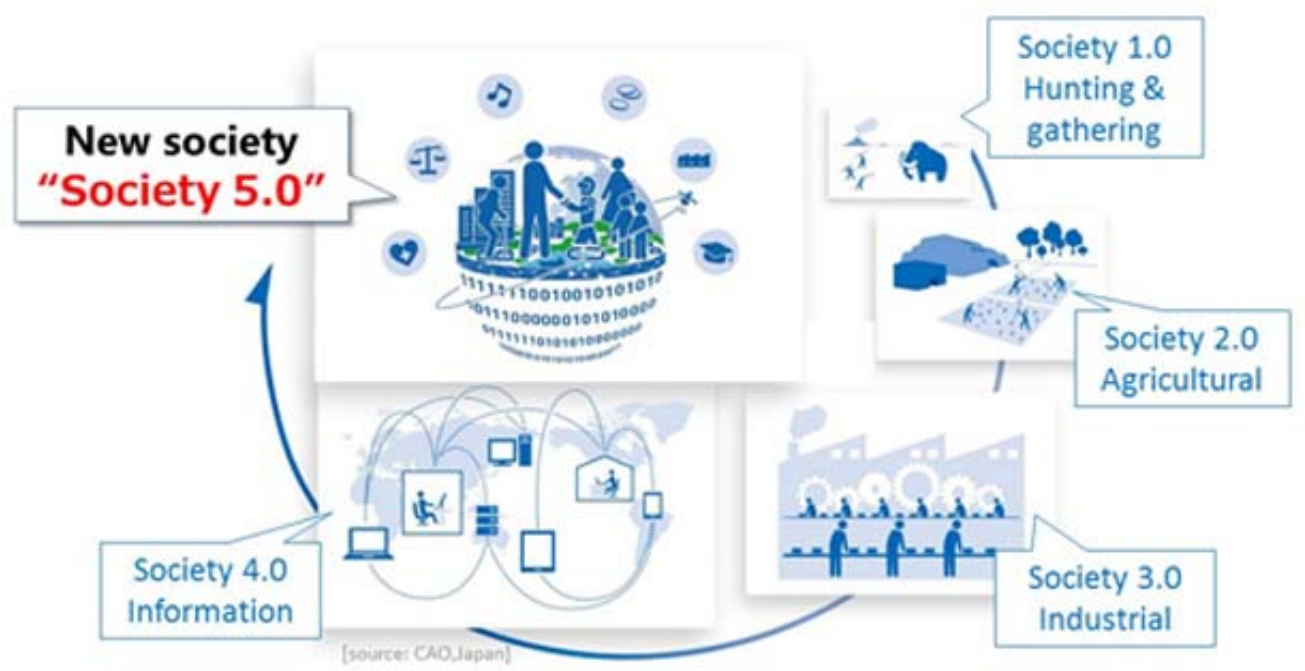

Source: Society 5.0. Cabinet Office ${ }^{16}$

Turkey's government and private sector made significant technological advances in 2019 , including a flying car, a domestically-produced electric vehicle and a laser gun, representing important steps in the development of its technology, defence and aviation sectors. The Turkish government continues to support the private

\footnotetext{
${ }^{15}$ Andrés Ortega, “Sociedad 5.0: El Concepto Japonés Para Una Sociedad Superinteligente”, Real Instituto Elcano, 2019, http://www.realinstitutoelcano.org/wps/portal/rielcano_es/contenido?WCM_GLOBAL_CONTEXT=/ elcano/elcano_es/zonas_es/ari10-2019-ortega-sociedad-5-0-concepto-japones-sociedad-superinteligente.

16 “Society 5.0", Cabinet Office, 2021, https://www8.cao.go.jp/cstp/english/society5_0/index.html.
} 
sector and education. In September 2019, 1.7 million people attended Turkey's largest aviation and technology event, Teknofest, at Istanbul's Ataturk Airport. The largest industrial fair in the Eurasian region, WIN EURASIA, was also held in March in Istanbul, bringing together more than 1,300 companies from various sectors. 127 scientists from 21 are engaged in academic research in Turkey as part of the government's scholarship program, which began in December 2018. Technology laboratories for children and young students were also set up in many cities across the country at the end of 2018. Turkey sent its third national Antarctic scientific expedition to the island of Podkve, one of the most remote places in the world, to set up a Turkish scientific research camp at the beginning of 2019; a threemember team from the Anadolu Agency also joined the expedition. ${ }^{17}$

Technological innovation better enables flexible forms of employment; classic flexible forms of employment particularly include temporary contract and part-time work; newer flexible forms include employment through employment agencies, remote work and worker rotation. In addition to the aforementioned flexible forms of employment based on national and European legislation, there are several completely new forms which depend on employer-employee agreement, but thus far they have no legal basis ${ }^{18}$. The labour market is constantly changing, new jobs and professions emerge and others cease to exist, and the causes of this change are different, including the economic cycle, public administration savings, competitiveness strengthening by means of efficient organization, technological progress and economic structure change, making it difficult to predict how jobs will develop in relation to digitisation.

\section{Discussion}

With constant change and digitalization, the nature of work will certainly change; 24/7 accessibility will make the boundaries between business and private life disappear, and work will be more intense; and this will negatively affect health, workrelated stress and working condition dissatisfaction. Employment policy must urgently respond to digitalisation's demands. It would be best if employment policy in relation to digitalization was active, that is, the effects of unemployment must be addressed and unemployment prevented, especially for those with low levels of education. Therefore, the main objective should be to form a more detailed view of education to create systems/arrangements to best enable the acquisition of the requisite skills and knowledge; and to this end, the state, employers and trade unions as a matter of importance must work closely together at the local and national level. Social systems/arrangements in Europe were able to maintain an enviable level of social security and well-being until a few years ago, but this is not the case today. The growth of non-standard forms of employment engendered by digitalization means that an increasing proportion of the labour force neither contributes to, nor takes advantage of established social security systems, such as unemployment, health and pension insurance.

\footnotetext{
17 Gökhan Ergöçün, “Turquía Encabezó Los Principales Desarrollos En Alta Tecnología Durante El 2019”, Anatolian Agency, December 30, 2019, https://www.aa.com.tr/es/mundo/turqu\%C3\%ADa-encabez\%C3\%B3los-principales-desarrollos-en-alta-tecnolog\%C3\%ADa-durante-el-2019/1687230.

${ }^{18}$ Eurofound, Trends in Quality of Life - Turkey: 2003-2012.
} 
Turkey's legislative and institutional framework provides for gender equality, but there are still gender gaps in such areas as employment, decision-making, education and health because legal enforcement is weak and support services are of low quality. The government has taken some positive steps to improve gender equality, as outlined in its action plans for education and employment, but these action plans have not been fully implemented, or systematically monitored. The legislative and institutional mechanisms needed to balance family and professional life as a fundamental component of all national policies to promote the employment of women are still lacking, even though gender equality laws have changed in Turkey over the years. Despite all of this effort, gender equality faces many challenges in Turkey.

\section{References}

Alviggi, Carlo, Sandro C. Esteves, Raoul Orvieto et al. "COVID-19 and Assisted Reproductive Technology Services: Repercussions for Patients and Proposal for Individualized Clinical Management". Reproductive Biology and Endocrinology. 18 (2020). https://rbej.biomedcentral.com/articles/10.1186/ s12958-020-00605-Z.

Aybars, Ayşe İdil, Paul Copeland and Dimitris Tsarouhas. "Europeanization without Substance? EU-Turkey Relations and Gender Equality in Employment". Comparative European Politics. 17/5 (2019): 778-796.

Cabinet Office. "Society 5.0". 2021. https://www8.cao.go.jp/cstp/english/ society5_0/index.html.

Ergöçün, Gökhan. "Turquía Encabezó Los Principales Desarrollos En Alta Tecnología Durante El 2019”. Anatolian Agency. December 30, 2019. https://www.aa.com.tr/es/mundo/turqu\%C3\%ADa-encabez\%C3\%B3-losprincipales-desarrollos-en-alta-tecnolog\%C3\%ADa-durante-el-2019/1687230.

Eurofound. Trends in Quality of Life - Turkey: 2003-2012 (European Quality of Life Survey (EQLS). Luxembourg: Publications Office of the European Union, 2014. https://www.eurofound.europa.eu/sites/default/files/ef_publication/ field_ef_document/ef1440en.pdf.

European Economic and Social Committee. "Opinion of the European Economic and Social Committee on the Impact of Digitalisation on the Service Sector and Employment in the Context of Industrial Change". Brussel, 2016. https://webapi2016.eesc.europa.eu/v1/documents/eesc-2015-00765-00-03-actra-sl.docx/content.

Infocop Online. "Cómo Asegurar el Bienestar en la Vuelta al Trabajo Tras la Pandemia por COVID-19”. June 3, 2021. http://www.infocop.es/view_article .asp? id=16886.

International Labour Organization. "Cambios en el Mundo de Trabajo". Conferencia Internacional Del Trabajo 95.a Reunión. 2006. https://www.ilo. org/public/spanish/standards/relm/ilc/ilc95/pdf/rep-i-c.pdf.

Karaalp-Orhan, Hacer Simay. "What are the Trends in Women's Labour Force Participation in Turkey?". European Journal of Sustainable Development. 6/3 (2017): 303-312.

Management Magazine. “Sociedad 5.0: La Profesión Del Futuro”. May 14, 2021. https://www.magazinemanagement.gm-bolivia.com/sociedad-5-0-la-profesiondel-futuro/. 
Ortega, Andrés. "Sociedad 5.0: El Concepto Japonés Para Una Sociedad Superinteligente". Real Instituto Elcano. 2019. http://www.realinstitutoelcano. org/wps/portal/rielcano_es/contenido?WCM_GLOBAL_CONTEXT=/elcan o/elcano_es/zonas_es/ari10-2019-ortega-sociedad-5-0-concepto-japonessociedad-superinteligente.

Sodja, Urška, "Vplivi Covid-19 Na Nekatere Vidike Kakovosti Življenja in Družbene Blaginje”, Kratke Analize, UMAR. 2020. https://www.umar.gov.si/ publikacije/kratke-analize/publikacija/news/vplivi-covid-19-na-nekaterevidike-kakovosti-zivljenja-in-druzbene-blaginje/?tx_news_pi1\%5Bcontroller $\% 5 \mathrm{D}=$ News\&tx_news_pi1\%5Baction\%5D=detail\&cHash=f042328151b2e46b d626b94ac212a215.

Turkish Statistical Institute. "Labour Force Statistics”. 2021. http://www.turkstat. gov.tr/PreHaberBultenleri.do?id=33778.

United Nations Human Rights Office of the High Commissioner (OHCHR). "Turkey: Withdrawal From Istanbul Convention is a Pushback against Women's Rights, Say Human Rights Experts", March 23, 2021. https://www.ohchr.org/en/NewsEvents/Pages/DisplayNews.aspx?NewsID=2 6936\&LangID=E. 